\title{
Middle Eastern Body-Building: The Construction of Dana International
}

\section{OREN MEYers}

Oren Meyers is a Ph.D. candidate at the Annenberg School for Communication, University of Pennsylvania. Meyers'main areas of research are collective memories, journalistic practices, and popular culture. He has recently written on the self-perceptions of Israeli migrants and on Holocaust commemoration in Israeli popular music. An earlier version of this article was presented at the "Sex on the Edge" conference at Concordia University, Montreal, in October 1998.

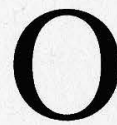

$\mathrm{n}$ the evening of May 9, 1998, an unusual crowd of cheering Israelis celebrated Dana International's victory in the Eurovision Song Contest, a competition in which 25 European countries, represented by their respective public broadcasting services, took part. After Dana's song Diva was announced as the winner of the contest, thousands of joyful Israelis rushed to Tel Aviv's Rabin Square. In a surprising juxtaposition, at least by Israeli norms, the rainbow flag was raised next to the blue and white national flag of Israel, and gay and lesbian activists danced in the company of enthusiastic fans of Betar Yerushalayim, the country's champion soccer team at the time, which is traditionally linked to right-wing and conservative sections of society (Ochovsky 25; Peri 3).

This somewhat surrealistic gathering in Tel Aviv's main square illustrates the complex role Dana International plays in the Israeli cultural and political spheres. Dana, born male-bodied in 1971, was originally named Yaron Cohen. She went through a sex change operation ${ }^{1}$ in

${ }^{1}$ In order to distinguish the surgical procedure Dana International went through,

torquere: Journal of the Canadian Lesbian and Gay Studies Association / Revue de la Société canadienne des études lesbiennes et gaies

Vol. 3 (2001) @) CLGSA / SCELG 
1993, and in recent years has occupied the spotlight at the intersection of gender, cultural, and political discussions in Israel. Although criticized by political activists and religious leaders, she has won the appreciation of hundreds of thousands of Israelis who not only bought her CDS, but also chose her as Israel's top woman singer of 1995.

The challenges posed by the varied forms of transgender representations to conventional perceptions of gender and sexual identities have been widely discussed (Butler 1-72, 128-34; Garber 93-117, 353-74; Goldsby 108-15; Stone 151-76) and much of this work has argued that gender is not inherent, but rather socially constructed or performed. Dana's case adds an important contribution to this body of knowledge since it positions the strain between essential and interpretive perceptions of gender and sexuality under unique circumstances. This is so because the Dana phenomenonwhich I define as the accumulated public outcome of Dana's construction through her body, through her performed images, through her artistic work, and through her dialogue with varied audiencesexists within the context of two interrelated frames of analysis. On one level, the ways in which Dana performs her images of femininity and sexuality challenge common perceptions regarding the meaning of 'being' a man or a woman. On a second level, this interplay between supposedly inherent traits and constructed images of gender merge into the complex politics of Israeli identity.

And so Dana's alternative reading of gender images is extended into an alternative reading of the tensions that shape Israeli reality. In a society that is, arguably, entering a "post-Zionist" era (Cohen 203-14) Dana embodies a trend of questioning longstanding truths. ${ }^{2}$ Through her musical choices and public personas, Dana underlines

I have decided to follow the works reviewed in this paper and define her as transsexual. At the same time, transsexuality is addressed as one of the many possible variations of transgender representation.

${ }^{2}$ See for example an article about Dana International by Amalia Ziv that was published in Te 'oryah u-vikoret (Theory and Criticism) special issue marking Israel's 50th anniversary through a survey of people, organizations, and events that represent a counterhegemonic reading of Israeli history. Another example of Dana's role in Israeli cultural discourse can be found in an interview with the novelist Abraham B. Yehoshua, one of Israel's prominent cultural and political thinkers (Koren). In the interview, Yehoshua offers a new model for state-religion relations in Israel based on the recognition that the Jewish people exist in an androgynous condition. "The androgynous are always more artistically rich," Yehoshua explained, "and it is not accidental that Dana International has become a national symbol over the last year" (26). 


\section{8 / Meyers}

tensions between essential and interpretive readings of religious and secular identities, Jewish and Arab cultures, and other standard Israeli categories of separation. In this sense, Dana is a clear threat to schools of thought that construct their arguments through essential distinctions between 'us' and 'them.' Thus, the mere fact that Dana was the official representative of Israel in the aforementioned Eurovision Song Contest stimulated angry responses from ultranationalistic and religious leaders (Sharrock 10).

But what is the mechanism through which Dana crystallizes issues such as gender and politics? And how does Dana's interpretation of those issues help her to be accepted by a variety of audiences? This paper aims to explore those questions through a study of Dana's work and public personas. The paper argues that the construction of Dana as seen through her body, her performed images, her artistic work, and her dialogues with audiences, reveals an ongoing dialectic process in which Dana simultaneously utilizes both essential and interpretive perceptions through changing circumstances. Thus the Dana phenomenon reflects a recurring pattern of working within and against gender, culture, and political conventions. In the cultural sphere, just as in the spheres of political or gender identity, Dana manages to convey unconventional or even subversive ideas through the constant use of accepted and legitimate imagery. Furthermore, the accumulated consequence of Dana's reading of Israeli reality is a reworking of diverse social spheres that are usually perceived as distant and unrelated.

\section{Four Means of Construction}

The following discussion probes four dimensions of the Dana phenomenon: Dana's body, her performance of public images, her artistic work, and her dialogue with various audiences. The connecting thread between these four components is their reflection of Dana's extraordinary ability to work simultaneously within and against common conventions of gender, culture, and politics in order to project her own messages. The analysis integrates relevant theoretical studies, works performed by Dana, and journalistic coverage. The theoretical studies considered here deal with various aspects of the tensions between essential and interpretive perceptions. Hence those works offer conceptual means that position the Dana phenomenon within the larger context of culture and gender studies. Moreover, those 
works provide several comparable and thus useful instances of cultural phenomena that underscore similar essential/interpretive strains. The material produced by Dana was gathered through a survey of the $\mathrm{CDs}$ and video clips she has released in the last eight years. The journalistic data was drawn from stories about Dana and interviews with her that appeared in six Israeli newspapers since 1993. Additional English-language stories were located through a Lexis-Nexis search.

\section{Construction through the Body}

Dana's body stands at the core of her self-definition and the discourse that surrounds her - two concepts that are, in many ways, inseparable. As a pop star Dana invests vast amounts of energy and money in order to maintain her physical appearance, and in interviews she has openly addressed her sex-change operation, consumption of hormones, and purchase of silicon implants. In many ways, Dana's example stretches Richard Dyer's (1-18) idea of the self-producing star to its limits: unlike other stars Dana was not satisfied with a nose job or a new hair color. In order to match her 'natural resources' to her image as a woman who is 'larger than life,' she went through the ultimate body transformation.

Dana's sex change, and especially the fact that the operation gained so much public attention, emphasizes the idea of the pop star's body as a commodity. Dana's drastic 'body upgrading' takes even the concept of the body as commodity (see Finkelstein 81-129) to its limits. While other stars may try to deny the fact that they consciously use their bodies to sell themselves and their sexuality, in Dana's case her body - which is undoubtedly 'constructed' - is to a great extent the message itself. This becomes clear while reading the interviews in which Dana continuously addresses issues of femininity and sexuality: she boasts about her sexual success with men (Kerem, "I Wouldn't Dare"), confesses about her desire to enlarge her breasts (Birenberg), and poses for news photographers in a variety of provocative (see figure 1) positions.

Dana's attitude toward the relation between her body and her gender identity is extremely complex. In the newspaper interviews given by Dana, she addresses her gender identity in three contradictory ways. In the clear majority of the interviews, Dana reinforces the concept of essential and binary gender division. In these interviews, Dana represents herself as a woman who was trapped inside a man's 
body and was liberated through surgery (Kerem, "What the Eyes See"). Furthermore, her former experience as a man is explained by her as "God's manufacturing error" (61). This logic strengthens the binary concept because it underscores that men and women are two essential parts of a dichotomy. Even the issue of transgender is not in conflict with the claim that Dana has always been a woman. It can be maintained that the physician merely helped her by exchanging her penis for a vagina, and so

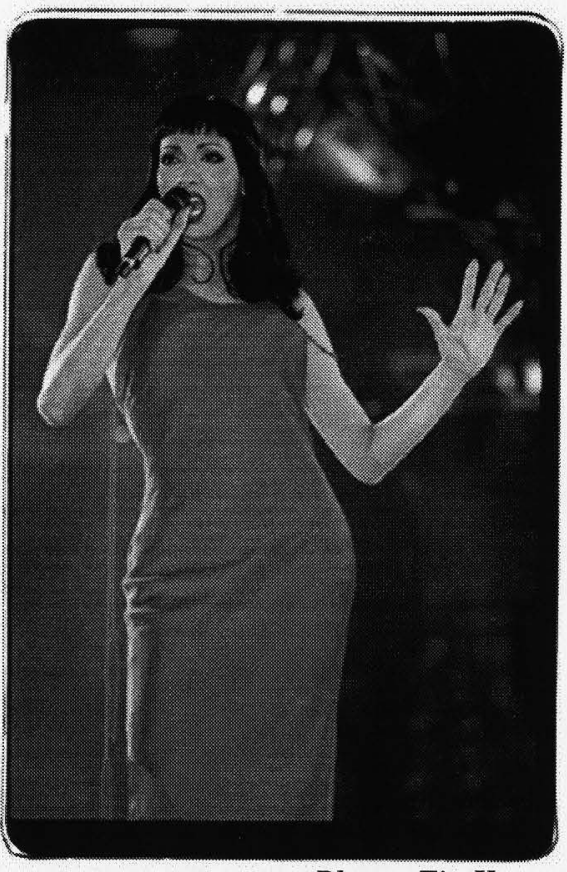

Photo: Ziv Koren fixed god's error.

Dana reinforces the notion that she has always been ' $100 \%$ woman' by repeating several types of stories that address her past and present. First, she tells stories that position her as the 'trapped woman' revealing, for example, that as a child she never wanted to dress up as a cowboy on Purim ${ }^{3}$ - the Jewish equivalent of Halloween - but rather as Little Red Riding Hood (Bar-On 12). In references to her current life she reinforces her femininity, not only by projecting her sexuality but also by telling reporters that many women consult her on 'feminine issues' (Birenberg 7). Furthermore, she addresses the most mythic aspect of femininity when she says she wants to have a child (Kotas, "International Family" 24).

The relation between Dana's body and her gender identity is extremely salient when it comes to coverage in the Israeli press. Since

${ }^{3} \mathrm{~A}$ Jewish religious holiday commemorating the preservation of the Jews in ancient Persia and celebrated by story-telling, dressing up in costumes, and partying. 
Dana has become famous, Israeli newspapers have on several occasions published claims from anonymous sources that Dana was never really operated upon and thus is not a 'real' woman. Such reports represent a more traditional and binary perception of gender division. Dana has responded by strengthening her feminine identity through recruiting witnesses such as family members (Kotas, "International Family") and ex-boyfriends (Riva), who confirm the fact that she has been surgically transgendered.

In contrast, two further interviews offer instances in which Dana presents more complex perceptions of her gender identity and bodygender relations. The interview with Ronit Foryan was given as Yaron Cohen in 1993, then still an active transvestite. A few months later, Cohen underwent the sex-change operation and became very famous through the success of his (then already her) first hit. In this first interview Cohen claims he is a gay man who only wears women's clothes in order to make money. He denies taking hormones and claims he has no intention of going through a sex-change operation.

The interview with Tzipa Kampinsky was given as Dana in 1996. By now she was very successful. The sharp difference between this interview and most others is that while all the others appeared in mass-circulation national dailies, this one appeared in Tat-Rama (Substandard), a gay publication of limited circulation. In this interview Dana remarks: "A transsexual went through an operation and she is grooming a breast, but at the same time, just like a homosexual, she loves to have sex with men. All of us will always be men" (qtd. in Kampinsky 6). Here, Dana also qualifies her present self-representation as a ' $100 \%$ woman' by saying: "Sometimes in interviews you have to beautify things. I have never felt I am a woman. If a woman who had a baby or went through an abortion should sit here next to me, I would never be able to feel like her. I never felt I am a woman, I just felt I am different" (qtd. in Kampinsky 2). The remarkable difference between three versions of Dana's gender identity as reflected in the interviews could be interpreted as a calculated manipulation or even as a string of lies. I argue, however, that if we adopt Sandy Stone's "Posttranssexual Manifesto" (15176) we must conclude that none of the abovementioned versions is a lie, just as none of them is true. Stone's analytical scheme suggests that these types of truth/lie binaries would not be adequate in a case such as Dana's. 


\section{2 / Meyers}

Stone stresses the idea that gender identities are in many ways social constructs, and often enough masculine and feminine characteristics are acquired skills. Her manifesto suggests that sexuality is a text that can be read - or rather performed - in alternative ways. The traditional concepts of binary gender divisions suppress the voice of transsexuals because they do not fit into either of the categories and therefore have to choose one and deny the other. When transsexuals manage to pass successfully to the other side of the gender border, they have to prove that the transformation was complete and that their old gender identity has been erased.

In contrast, the textual interpretation of sexuality broadens the scope of possible gender options by delineating a certain reversibility. Because there are a variety of options in regard to gender identity, the idea of a man trapped in a woman's body or vice versa is no longer relevant. And so, if sexuality can be perceived as a text, then Dana simply reads her sexuality as different gender-genres under different circumstances. This can be true both for different interviews catering to different audiences and for different life phases. Sometimes Dana prefers to read or perform her sexuality as a man, sometimes as a woman, and sometimes as 'something different.'

\section{Construction through Performed Images}

Dana's identity is - or identities are - produced through a series of contrasting public images she performs in different contexts. The first and most significant set of such contrasting images are related to Dana's feminine identity. In her public appearances Dana shifts between two poles: she is either the 'ultimate femme fatale,' defined by her sexuality and extraordinary talent to manipulate men, or she is the 'little loyal woman' who truly worships her man (Kotas, "Dana"). By the same token she moves between promiscuous sex and family values or between cynicism and romance. Thus, for instance, she criticizes other Israeli women singers for not being sexy and provocative enough (Kerem, "What the Eyes See" 62), but at the same time she says she pays heed to her boyfriend's complaints that she is not modest enough (Kotas, "Dana" 18).

In this context it is worth examining how Dana utilizes her boyfriends in the process of constructing her images. In her first reference to the subject Dana claims she has a boyfriend serving as an officer in a paratroopers unit of the Israeli army. Though the 
boyfriend was never publicly identified - and thus might be totally fictional - Dana's continuous references to his service in a combat unit links her to the classic Israeli macho fantasy of the girl who is in love with the tough warrior. A second boyfriend was interviewed together with Dana, and the portrayal that emerged was that of an extremely traditional and chauvinistic relationship. Although the boyfriend was unemployed at the time and Dana's work was the main source of income in their household, she keeps mentioning that she cooks for him and washes his clothes. "With all due respect for my achievements," she said, "love is more important to me than my career. And I also know that it does not matter to Nissim [the boyfriend] if I finish first or second in any song contest. For him, the most important thing is that I am his woman" (Kotas, "Dana" 16).

The common characteristic of those contradictory female images is that both are exaggerated to the extent that they no longer reflect a 'real' woman, but rather hyperbolized symbols of femininity. As a seductive slut or as an obedient homemaker Dana is self-reflectively performing the role of a stereotyped woman. Dana's choice of these extreme representations could be interpreted in two contradictory, or rather complementary ways. On the one hand, it is possible to claim that Dana's frequent shifts between clichéd feminine images - even if they are caricaturistic in nature - reflects her sophisticated use of the "politics of signifier" (Kaplan 158). By performing those different images under different circumstances, Dana rejects essential binding definitions. Her constant use of varied images does not conceal some hidden 'true' self, but rather demonstrates the possibility of personal and political self-invention. Her identity-shifts thus have subversive potential.

On the other hand, it is also possible to argue that Dana performs these kinds of exaggerated feminine images since she has no other choice. Under the current conservative Israeli circumstances (see for example, the aforementioned journalistic inquiries regarding the operation, or the religious reactions to Dana), Dana is unlikely to be considered an 'ordinary' or 'normal' woman. Thus the only way for her to pass as a woman is to poach those unrealistic, or even hyperrealistic, feminine images.

Dana's identity is likewise constructed through contradictory, performed images in the context of Israel's social reality. This begins with her name: when Dana decided to replace Yaron Cohen with a 


\section{4 / Meyers}

new invented name she chose "Dana International," a name that combines two contrasting concepts. While "Dana" is a very typical Israeli name - one frequently mentioned in children's songs "International" obviously reaches beyond the scope of the Israeli nation-state. The same concept is evident in the way Dana positions herself between east and west. She sings in Hebrew and Arabic, but also in English and French. In the same way, her music combines Western dance music with traditional Middle Eastern rhythms.

This choice should be understood in the context of the ongoing negotiation, or struggle, over Israel's cultural identity. Although in the first few decades of its existence Israel absorbed hundreds of thousands of Jewish migrants from Middle Eastern countries, its political and cultural agendas were determined by the dominating Ashkenazi elites (i.e., of European origin). This type of relationship between Jews of Middle Eastern and European origins continued to a significant extent into the next generation. So wide gaps between the two groups still exist in the realms of education, income, occupational status, and social mobility (see esp. Smooha and Kraus).

In the last decade or so, and after years of relative marginalization (see Regev), Middle Eastern music has managed to make its way into Israel's cultural mainstream. Dana is undoubtedly among the leading artists contributing to this process. Her presentation of mixed rhythms and texts in different languages, including Arabic, would have been virtually unthinkable in terms of the mainstream Israeli cultural scene twenty or thirty years ago (see Alcalay 220-38).

In my opinion the most interesting coupling of contrasting images can be found in Dana's relationship with god and religion. For obvious reasons Dana is not well-liked by the religious sections of Israeli society, and some municipal rabbis have tried, sometimes successfully, to prevent her from appearing in their towns (Fishbein 19). On several occasions, Dana has attacked Israel's religious establishment and expressed fear about the growing strength of the religious parties. At the same time, Dana keeps emphasizing that she believes in god (BarOn 11) and thinks it is important that young Israelis should know more about their Jewish heritage (Kerem, "I Wouldn't Dare" 57).

But the most unusual way in which Dana links herself to Judaism is through a story about the way she found out about "God's manufacturing error" (Bar-On 12; Kerem, "What the Eyes See" 62). This revelation occurred on her (then his) bar mitzvah, the Jewish 
rite of passage from childhood to adulthood that every Jewish boy is supposed to go through when he is 13 . On his bar mitzvah day Yaron Cohen went with his family to the Western Wall in Jerusalem, the most sacred place to the Jews. While he was approaching the wall, an Ultraorthodox Jewish man saw Cohen turning to the men's section of the Wall and told him that young girls should go to the other section. Dana explains that, at that moment, she knew she was a woman. This appropriation of the Jewish cultural-religious rite of passage into Dana's personal-sexual rite of passage between the genders positions her individual narrative within the context of some major cultural narratives. By choosing to tell this specific story Dana demonstrates her strategic ability to poach the symbols of mainstream Jewish-Israeli discourse (bar mitzvah, the Western Wall) while charging them with subversive messages.

\section{Construction through Artistic Work}

In order to discuss Dana's use of her artistic work, I address four examples.

The song "I Can't Do without You"4 was among Dana's first hits. In order to analyze it accurately it is important to note that in Hebrew, verbs and nouns have male and female suffixes that enable the listener to understand that when Dana sings "I Can't Do without You" it is clear that she is a woman who is addressing a man. The text corresponds with typical feminine submissive imagery through lines such as "You can tell me/ that the night is over/ that you have to $\mathrm{go} /$ that it is becoming late/ but don't tell me/ that you don't want me anymore." The song portrays a woman who is totally dependent on her one and only man, perhaps the loyal wife waiting for her husband to return home from his mistress, or the 'other woman' frustrated with her man who is able to escape from his family only for a brief moment. In either case it is clear that the text corresponds with the traditional, negative stereotype of the emotional woman who is totally controlled by a dominant man.

When Dana sings this simplistic text it can be interpreted in two contradictory ways: on the one hand, it fosters her 'little woman' image, which is also emphasized in some of the interviews she has given. On the other hand, Dana's singing of this kind of stereotypical

${ }^{4}$ Lyrics: Max Gat-Mor; melody: Tzvika Pik. 


\section{$86 /$ Meyers}

text can also be interpreted as a parody on traditional gender relations. Dana's choice to cross the border between genders is reflected in her theatrical and larger-than-life performance of this song, and suggests that her reading of the text is a form of ridicule. Her ability to read herself as the 'little woman' can be regarded as part of a costume game, or as a part of her ongoing process of self-invention. Under these circumstances her use of such a text could be grasped as a critical or liberating act.

The liturgical poem "Freedom Shall Be Bestowed" (Dror Yikra in Hebrew), praising god for giving the Sabbath to the Jewish people as a day for rest and worship was written by the ancient, mid-tenth century Jewish scholar Dunash Ben Labrat (see Popper 13) and it is usually sung around the family dinner table on Friday evening. When Dana sings this song she is linking herself to two traditions. First, she connects herself to her Jewish roots, just as she has aimed to do in other contexts. Second, she is relating herself to other famous Israeli singers, mostly men and women of Yemenite Jewish origin (Ofra Haza and Boaz Sha 'arabi, to name two well-known examples) who already performed their versions of this notable poem.

Yet, when Dana sings "Freedom Shall Be Bestowed" she offers an alternative reading of the text, an instance of cultural poaching. This is first emphasized through the rhythm of her singing. Although Dana follows the traditional melody, she adds to it a Western rhythm that makes it sound like a typical dance song. Secondly, when especially Dana sings the declaration that "Freedom shall be bestowed upon a boy and a girl/ and he shall guard you as if you were the apple of his eye" the poem is undoubtedly charged with a different and new meaning, that shifts its focus from a religious-moral intent to a sexual one. The freedom for "boys and girls" can be interpreted in a very nontraditional way as a call for unhindered sexual selfexpression.

The song "There Are Girls" was originally sung by a military musical troupe in the 1960s and since then it has gained the status of a classic Israeli pop song. Since the establishment of the state of Israel in 1948 and until the mid 1970s, the military singing troupes, comprised of young men and women in uniform, were among the most popular musical groups in the country. The military groups' soloists were treated like rock stars and their alumni dominated Israel's civilian popular music scene. 
"There Are Girls" is a typical song from the golden age of the military troupes. Although it does not directly address military issues, it certainly reinforces traditional patterns of interaction between men and women that were so common in the Israel Defense Forces (IDF). The song deals with the traditional division between 'good' and 'bad' girls. The good girls act in accordance with what is socially acceptable for young girls, while the bad ones are promiscuous and thus manage to seduce all the good guys: "There are girls, there are girls/ they dress up like cover girls/ their skirts get shorter and shorter/ and there are so many holes in their blouses/ that any guy can come and choose."

Dana's cover of "There Are Girls" links her to the origins of Israel's pop culture and to the IDF's unique folklore. That Dana chose to cover this specific song is not accidental. In its original version, when performed by the military troupe, "There Are Girls" was ironic in the way it supposedly represented the complaints of the good girls, while in truth mocking them. Dana's version offers us another ironic twist. First, we tend not to take Dana's claim about identifying with the complaints of the good girls so seriously. This is somewhat similar to Madonna's claim that she feels "like a virgin." It is clear that the emphasis should be put on the word "like," since Madonna's projected image is far from virginal. In Dana's case it is clear that she is hardly a good girl, since the image she projects tends to be provocative.

Second, when Dana sings "But I'm not like that/ but I'm not like that/ I am usually demure/ so no one bothers with me" the popular verse gains a whole new dimension of interpretive options: why is Dana not "like that," and what exactly makes her different from other girls? After dismissing the idea that Dana is protecting some imagined chastity, we are left with the ironic-subversive option: what is the "that," or the essence of any gender or sexual identity? Are the differences between types or genres of girls inherent or are they culturally constructed? And what about the differences between girls and boys? This type of interpretation is reinforced in the video clip of "There Are Girls." It features a mocking militarylike parade of dancing women, dressed in different costumes representing different 'genres' of professional feminine identity: a nurse, a policewoman, a teacher, a showgirl, and so on. While answers to questions of feminine

'5yrics: Yoram Tehar-Lev; melody: Ya 'air Rozenblum. 
identity can vary, it is clear that Dana's use of this text adds a completely new layer of meaning to its conventional rhetoric.

The video clip of the song "Cinquemilla" provides another example of the self-reflective dimension of Dana's works as well as of her intensive dialogue with her audience. In the clip, Dana is portrayed in her larger-than-life image as a sexy and seductive woman. During a significant portion of the clip Dana is filmed while she is riding passionately on an enormous artificial banana. This image directly addresses Dana's questionable gender identity, since it is hard to ignore the visual hint that Dana is riding a larger-than-life penislike object.

The decoding of this charged image can be assisted by considering Garber's concept of "male subjectivity" (95-96) as a way of perceiving traditional gender definitions as determined by men. At the core of this "male subjectivity" stands the male phallus; its existence or absence is the ultimate gender definer. This fundamental assumption guided male physicians and psychologists while dealing with transvestite and transsexual patients, rendering the core definition of gender as determined by their relationship with their penis: a male patient who looked like a woman, talked like a woman, and thought of himself as a woman, but still 'operated' his penis in order to gain sexual pleasure was a man confronting a psychological crisis. At the same time, a man who wanted to go through an operation in which he would lose his penis was deemed a 'woman trapped inside a man's body.'

Dana's intentional choice of riding an object that clearly resembles a male penis touches upon the most sensitive aspect of "male subjectivity" the fear of castration. In this context Dana's control of the penis signifier represents her triumph. Just when she got rid of it and replaced it with a new kind of gender identity, she finally managed to master the male penis. This interpretation is validated by a radio interview Dana gave after the clip won the first prize in the video clips category at the Haifa Film Festival. Dana was asked about the inspiration for the clip's main metaphor. She replied that some time before the clip had been shot an Israeli standup comedian had mocked her by joking: "Poor Dana, somebody cut off her banana." Riding the enormous fake banana was Dana's response. 


\section{Construction through Audiences}

It is impossible to talk of a singular way in which Dana is perceived by her audiences. ${ }^{6}$ By the term "audiences," I do not refer only to those who buy Dana's CDs, but also to the many people who find it necessary to address her publicly. Dana's ability to position, or rather reinvent herself, within many cultural contexts corresponds with the reactions of her audiences. And so she is perceived by various parties - both followers and opponents - in different and, in many cases, contradictory ways.

Dana's relationships with her audiences have a clearly circular nature. As explained above, Dana constructs her identities in several simultaneous political, cultural, and sexual spheres. Different audiences perceive these fragmented identities in a variety of ways, then Dana formulates her public reply, and so it goes on, enriching and layering the Dana phenomenon. Furthermore, the mosaic of perceptions about Dana stresses the noninherent dimensions of the Dana phenomenon even more, making it clear that Dana means very many different things to various audiences at one and the same time.

There are several distinct audience perceptions of the Dana phenomenon that I wish to discuss here. The first perception is that of Dana's Israeli fans and especially those who belong to the gay community. As previously mentioned, in the last eight years Dana has sold hundreds of thousands of albums in Israel, and since her success in the Eurovision she has also released several albums targeting international audiences. Those fans who have bought Dana's albums are obviously supportive of Dana's musical projects, but beyond that Dana has also gained the status of a hero among homosexuals, lesbians, and the transgendered across the world, and especially in Israel. ${ }^{7}$ For instance, following Dana's victory in the Eurovision, Yair Keidar, the editor of Hazman Havarod ("The Pink

${ }^{6} \mathrm{~A}$ similar phenomenon was discussed in Kaplan's analysis of the three possible perceptions of Madonna. The first, conservative perception positions her in the "perversion" frame. The second perception, common among culture critics, follows Theodore W. Adorno and Max Horkheimer's tradition by positioning Madonna in the "repression" frame. The third perception is attributed to teenage girls, and it positions Madonna in the "subversion" frame since she offers young girls a revolutionary type of role model, embodying a new kind of feminism.

${ }^{7}$ See for example Dana's web page on $<$ http://www,gay.org.il/asiron>, the web site of the Gay and Lesbian Student's Union of the Hebrew University. 
Times") commented: "It is the best thing to happen to the gay community here in 50 years. Dana got where she got without forgetting where she came from" (qtd. in Keinon 8).

This wave of support is undoubtedly related to the fact that, throughout her career, Dana has always spoken openly about her gender identity and about her past experiences as a gay man. Furthermore, Dana has performed for free at events organized by gay associations, sung at the opening of the 1998 Gay Games in Amsterdam, and supported the struggle for gay rights in Israel. This behavior is unique on the Israeli pop scene, where Dana is one of the few singers who publicly addresses her nonnormative sexual preference or gender identity.

But Dana's identification with the gay community, binding gender identity with sexual preference, is not always viewed as natural or inherent. For example, Amit Kama, the former chairperson of Israel's association for the protection of individual rights (an organization representing Israeli homosexuals, lesbians, and bisexuals) made the following comment: "II refuse to include Dana International in the homosexual scene. There is much less of a common denominator between her and myself than there is between you [the heterosexual woman reporter] and myself. I am enraged when people tell me she contributed to our community. She is neither a homosexual nor a lesbian"' (qtd. in Kampinsky 6). Later Kama softened his criticism, while still expressing some uneasiness regarding the way Dana ties homosexuality with transsexuality, thereby suggesting what gay men really want is to become women (Levertov 9). Michal Maroni-Fenner, an Israeli lesbian activist, revealed a similar conflicting view regarding Dana. According to her, the transgendered are an integral part of the gay community since they all "undergo a shared oppression" (Levertov 11). At the same time, she claims that it is hard for her as a lesbian feminist to embrace Dana as a role model since "she represents the most stereotypical woman there is, heavily made up, and with her breasts hanging out."

These contrasting responses again illuminate the fluid and complex components in Dana's public image. Her past experiences as a gay man, her diligent support of the gay community, and the fact that most of her entourage is made of gay men position her as a spokeswoman for the community. At the same time, her decision to abandon her male gender identity and her current self-positioning as 
a feminine sex symbol seem to undermine - at least according to some community members - the causes both of homosexuals and of lesbians.

The second public perception I wish to discuss is that of Ultraorthodox Jewry. As mentioned previously, certain rabbis have tried to prevent Dana from performing in their towns, and in other instances managers of wedding halls refused to let Dana film video clips in their halls for fear that they would lose the kosher certification. Also, a striking piece of anecdotal information that came to light after the murder of Yitzhak Rabin, Israel's late prime minister, seems all too revelatory in this context. The investigators found that before the assassin Yigal Amir shot Rabin, he was waiting in the parking lot and speaking with some of the policemen guarding the area. At the same time, Aviv Geffen - another controversial Israeli singer - was singing on the stage as a part of the peace rally. According to the testimony of the policemen, Amir commented upon Geffen's performance by saying: "well, at least we are lucky they didn't bring that androgynous Dana International to the stage" (qtd. in Kampinsky 5).

This story, together with other less sensational ones, reveals the fact that Dana has gained the status of a symbol in the most intense dispute dividing the Jews of Israel. Since the establishment of the "State of Israel," its citizens have fiercely debated the question of Israel's religious and cultural identity. The fundamental issue is whether Israel ought to be specifically a "Jewish State," with all of the relevant religious implications, or only a "state of the Jews," which is to say a more-or-less secular homeland for the Jewish people. ${ }^{8}$ This dispute has been manifested over the years in a series of debates on questions ranging from the exact interpretation of the Law of Return (i.e., how to determine the qualifying criteria for being Jewish) to quarrels over the closing of specific streets during the Sabbath.

Following the 1967 Six Day War and the growing dispute over the future of the occupied territories, the religious rift has increasingly overlapped with the political-strategic one, increasingly dividing the Jewish population into two opposing groups affiliated with two

${ }^{8}$ There is also a third option, less popular among Israeli Jews, that Israel should be the state of "all its citizens," which is to say it should abandon its Zionist vision. 
opposing world views. This tension has caused several researchers to argue that present day Israeli society is in many ways on the brink of a culture war, if not an actual civil war (see esp. Etzioni-Halevy 726; Ohana 9-27).

In this context, Israel's conservative and religious sectors view Dana as more than a curiosity. Dana, a proud transsexual and a vocal supporter of gay causes embodies, as her opponents see it, the dangers of an Israel that is secular and immoral. She is a symbol of a public alienated from its Jewish heritage and, thus, bound to lead to the country's destruction, or at least to the abandonment of its Jewish identity. Following Dana's victory in the Eurovision, Shlomo Benizri, Deputy Minister of Health and a representative of the Ultraorthodox Shas Party, stated: "God is against this phenomenon. It's a sickness you must cure rather than give legitimacy" ("T*Dana").

Dana's assertions that she is a firm believer in god, and her constant appropriations of national and religious symbols as a means of conveying her nontraditional messages represent a challenge and threat especially to religious leaders. One instance of such appropriation was evident when Dana took part in Amnesty International's human rights campaign. Her poster titled "Gay Rights Are Human Rights" featured her in a relatively modest outfit, wearing a head cover, as she holds a lighted candle, which is both the logo of Amnesty International and a potent symbol of traditional Jewish womanhood. Following the same pattern, Dana's insistence that she is an Israeli patriot and that her victory in the Eurovision was her "gift for Israel's 50th anniversary" (Gozani 7) clearly demonstrate why she is viewed as a sophisticated threat by religious and ultranationalistic elements.

The two final perceptions I wish to discuss are found, respectively, among Dana's Arab fans and Egyptian officials. As mentioned, Dana sings in several languages, including Arabic, and her music combines Middle Eastern and Western rhythms. This formula has made her extremely popular in neighboring Arab countries, and according to some estimates six million bootleg Dana cassettes were sold in Arab countries up to July 1996 (Kerem, "Operation Dana" 46). When the Egyptian authorities discovered that Dana had become a favorite of Egyptian music fans they denounced her cassettes as abominations and forbade their distribution. Articles in the Egyptian press later claimed that Dana's successful "penetration" of the country was part 
of a "Zionist scheme to corrupt Egypt's youth" (Karem, "Operation Dana" 46).

Those far-fetched allegations should be understood in the context of Israeli-Egyptian relations. Although the two countries signed a peace treaty 21 years ago, their relations are usually described as a "cold peace." Furthermore, the normalization process between the countries does not stop Egyptian newspapers from continuously publishing stories that accuse Israel of spreading AIDS in Egypt, increasing prostitution, and so on. These new themes relate to the old accusation that Israel is the most powerful representative of Western imperialism in the Middle East.

There is of course some irony in the fact that while Dana is still struggling in some respects to gain legitimacy in Israel, she is perceived elsewhere as an official representative of the Israeli authorities. Beyond that, it seems as though the fears of Egyptian officials are similar in nature to the ones expressed by the Jewish religious establishment in Israel. Dana is popular among Egyptians and other Arab pop music fans because she manages to provide a musical fusion of the local and the international. It is feared that this appropriation of local Middle Eastern culture (or Jewish tradition and Israeli patriotism in the Israeli case) may make her fans less immune to her subversive contents. Furthermore, just as in the case of Orthodox Judaism, Dana's Egyptian critics have been arguing that appropriation of cultural and religious assets is superficial and misleading. Hence, a Cairo Times reporter commented that Dana's songs are "laden with Arabesque clichés of what the West thinks is an Oriental sound; coupled with the use of colloquial language, screeches, and grunts, it all evidences a level of impropriety one doesn't find in bona fide Arabic pop music. It's all very contrived and not a little condescending" (Hammond 7).

Just as in other such instances, Dana articulated a reply to this perception of her, this time by means of cultural-commercial appropriation: she agreed to be a leading model in a fashion catalogue that was shot in Egypt. Thus, in what was described as "Operation Dana" (Kerem), she was sneaked into Egypt and photographed wearing miniskirts and other attire in front of the pyramids and while cruising on the Nile. 


\section{4 / Meyers}

\section{Conclusion}

The main purpose of this paper has been to analyze the inner workings of the Dana phenomenon, that is, to explore the mechanisms through which Dana International constructs her varied identities. This investigation has revealed a sophisticated mixture of self-awareness, constant cultural quotation, and ongoing self-invention, a blurring of the borders between high and low cultures, a breaking of the links between signifiers and marked entities, and other familiar elements of the postmodern inventory (see Jameson).

But Dana is more than a cultural rarity or a postmodern poster girl. Her ongoing juggling of images and identities is not arbitrary nor is it located from her surroundings. Instead, it is a result of her interaction with Israeli identity. Dana's sophisticated use of elements such as her traditional Jewish background, her stated belief in god, or the lyrics of an old song from the army troupes' repertoire relates her to a specifically Israeli collective reservoir of images and memories. Her poaching of Israeli mainstream culture enables her to use those cultural tools in a way that undermines the conservative and traditional attitudes and beliefs they otherwise maintain. This is precisely the reason she is embraced by so many Israelis while feared and loathed by others.

In a larger sense Dana not only plays with the fundamental elements of Israeli reality, she also alters them. Her conscious decision to construct her gender identity through a complex set of images seems to permeate other dimensions of Israeli life. Following the same pattern, Dana constructs herself in the context of religion, nationality, and cultural orientation in ways that seem also to undermine the accepted underlining binary nature of these categories. She offers an interpretive performance not only of gender and sexuality, but also of the relations between secularism and religion, East and West, and Jews and Arabs. Her main subversive contribution in doing so is that she manages to embody all of these conflicting cultural and political personas simultaneously, thus challenging their inherentness. In this sense she truly challenges the society in which she lives.

I wish to thank Laura Grindstaff and Barbie Zeitzer for their comments on previous versions of this article. I also wish to thank Ziv Koren and Roni Rabinovitch for taking and obtaining the photograph 
accompanying this article.

\section{Works Cited}

Alcalay, Ammiel. After Jews and Arabs: Remaking Levantine Culture. Minneapolis: University of Minnesota Press, 1993.

Bar-on, Ya 'akov. "“I Come to My Audience as a Woman Singer and

Not as a Gimmick."” (In Hebrew) Laisha 2 May 1994: 10-13. Birenberg, Yoa 'av. “'What Can I Tell You Yoa 'av? We Have a Wonderful Country and a Wonderful People."' (In Hebrew) Yedioth Ahronoth 23 Aug. 1996: 6-7.

Butler, Judith. Gender Trouble: Feminism and the Subversion of Identity. New York: Routledge, 1990.

Cohen, Eric. "Israel as a Post-Zionist Society." Israel Affairs 1 (1995): 203-14.

Dana International. "I Can't Do without You." Umpatampa. IMP, 1994.

—. "Freedom Shall Be Bestowed." Umpatampa. IMP, 1994.

—. "There Are Girls." Umpatampa. IMP, 1994.

—. "Cinquemilla." Diva. IMP, 1998.

Dyer, Richard. Heavenly Bodies: Film Stars and Society. New York: St. Martin's, 1986.

Etzioni-Halevy, Eva. The Divided People. (In Hebrew) Kefar-Sava, Isr.: Arye Nir, 2000.

Finkelstein, Joanne. The Fashioned Self. Philadelphia: Temple University Press, 1992.

Fishbein, Anat. "Dana is Singing, But Not in Tiberias." (In Hebrew) Iton Tel Aviv 13 Oct. 1995: 19-20.

Foryan, Ronit. "My Name is Not Dana." (In Hebrew) Iton Tel Aviv 21 May 1993: 36-39.

Garber, Marjorie. Vested Interests: Cross-Dressing and Cultural Anxiety. New York: Harper, 1993.

Goldsby, Jackie. "Queens of Language: Paris is Burning." Queer Looks. Ed. Martha Gever, Pratibha Parmar, and John Greyson. New York: Routledge, 1993: 108-15.

Gozani, Ohad. “Israeli’s Song Win 'Defeat Bigotry.” Daily Telegraph 11 May 1998: 7.

Hammond, Andrew. "Girls Just Wanna Have Fun." Cairo Times 15 May 1997: 7-8. 
Jameson, Fredric. "Postmodernism, or the Cultural Logic of Late

Capitalism." Twentieth-Century Literary Theory: A Reader. Ed.

K. M. Newton. New York: St. Martin's, 1997. 267-75.

Kampinsky, Tzipa. “"In the Same Place a Homosexual Gets a Bottle

Thrown at His Head, a Cokesinelle Will Receive an Indecent

Proposal."' (In Hebrew) Tat-Rama 2 (1996): 2-6.

Kaplan, Ann E. "Madonna Politics: Perversion, Repression, or

Subversion? Or Masks and/as Master-y." The Madonna

Connection. Ed. Cathy Schwichtenberg. San Francisco: Westview, 1993. 149-65.

Keinon, Herb. "A Victory Not Celebrated by Everyone." The Jerusalem Post 11 May 1998: 8.

Kerem, Shay. "'I Wouldn't Dare to Grade a Cokesinelle at the Top of the Chart."' (In Hebrew) Yedioth Ahronoth 2 Dec. 1994: 5657.

- . "Operation Dana." (In Hebrew) Yedioth Ahronoth 19 July 1996: 44-50.

."What the Eyes See Now is Not Always the Truth." (In Hebrew) Yedioth Ahronoth 10 Dec. 1993: 60-62

Koren, Anat. "On the Nature of Our Androgen Identity." (In Hebrew) Toa 'ar Nov. 1998: 24-26.

Kotas, Chen. "Dana and Niso.” (In Hebrew) Ma 'ariv [Yom Kippur supplement] 3 Oct. 1995: 16-18.

__ . "The International Family." (In Hebrew) Ma 'ariv 10 Mar. 1995: 21-25.

Levertov, M. "The Body in Question." Ha 'aretz 22 May 1998: 8-11.

Ochovsky, Gal. "The Success and Gaultier's Parrot." (In Hebrew) Ma 'ariv 15 May 1998: 27-28.

Ohana, David. The Last Israelis. (In Hebrew) Tel Aviv: Hakibbutz Hameuchad, 1999.

Peri, Tal. "I Proved That in This World There Is Also a Place for My Way of Life." (In Hebrew) Ma 'ariv 11 May 1998: 2-3.

Popper, William. "Dunash Ben Labrat." The Jewish Encyclopedia.

Vol. 5. Ed. Isidore Singer. New York: Funk \& Wagnalls, 1906. 11-13.

Regev Motti. "Organizational Fluency, Organizational Blocks, Cultural Relevance: The Case of the Music Industry in Israel." (In Hebrew) Te 'oryal u-vikoret 10 (1997): 115-32. 
Riva, Gil. "'She Was Operated, She is a Complete Woman.” (In Hebrew) Col Ha'air 27 Sept. 1996: 78-81.

Sharrock, David. "Real Lives: The Very Other Dana." The Guardian 31 Dec. 1997: 10.

Smooha, Sammy and Vered Kraus. "Ethnicity as a Factor in Status Attainment in Israel." Research in Social Stratification \& Mobility 4 (1985): 151-75.

Stone, Sandy. "The Empire Strikes Back: A Posttranssexual Manifesto." Camera Obscura 29 (1992): 151-76.

"T* Dana Wins Eurovision Contest." PlanetOut.com. May 11, 1998. Ziv, Amalia. "Dana International." (In Hebrew) Te'oryah u-vikoret 12-13 (1999): 401-11. 